\title{
Appropriation of restorative justice in the prevention, management and resolution of Niger Delta conflicts
}

\author{
Elias Ewa Kekong Bisong \\ Promotor: Tom Vander Beken \\ Vakgroep Strafrecht en Criminologie, Universiteit Gent
}

Openbare verdediging: 26 juni 2008

Dit proefschrift onderzoekt welke mogelijkheden het herstelrecht biedt bij het voorkomen, beheersen en beslechten van conflicten in landen die getroffen worden door grote sociale onrust, met de Niger Delta als gevalstudie. Deze regio is rijk aan natuurlijke grondstoffen (vooral olie), maar wordt tegelijk geplaagd door grote sociale onrust, criminaliteit en zelfs gewapende conflicten. De ongelijke verdeling van de lusten en lasten van de olie-inkomsten, de aanwezigheid van internationale olieconcerns en hun vernietigende impact op het leefmilieu, de verpaupering en marginalisering van de lokale bevolking leid(d)en tot opstanden tegen de staat en de oliebedrijven. De dominante reactie op die conflicten was tot nog toe hoofdzakelijk repressief en bevestigt en bestendigt vooral de bestaande krachtverhoudingen. Voor het bewerkstelligen van duurzame (sociale) vrede is deze reactie contraproductief en stuit op steeds groter wordend verzet van de bevolking.

Een alternatief voor de repressieve aanpak van conflicten is de herstelrechtelijke benadering. Deze benadering wordt internationaal steeds belangrijker en de principes ervan werden door verschillende landen reeds op diverse manieren in de praktijk gebracht. Het vernieuwende van deze benadering is dat (in tegenstelling tot de klassieke strafrechtelijke benadering) niet de bestraffing centraal staat, maar wel het herstel van de aangerichte schade. Het doel van dit onderzoek is dan ook om na te gaan in welke mate een herstelrechtelijke benadering een alternatief kan vormen voor het voorkomen, beheersen en beslechten van de conflicten in de Niger Delta.

In dit onderzoek is gekozen voor een brede en multidisciplinaire benadering waarbij een in essentie juridische vraagstelling rond recht en conflict wordt gecontextualiseerd door ook elementen van buiten het recht zelf te betrekken. Het uitgangspunt van dit onderzoek is immers dat de conflicten in de Niger Delta enkel kunnen worden begrepen, voorkomen en opgelost, indien ook de oorzaken ervan in kaart worden gebracht en hun relatie tot de huidige juridische situatie wordt geduid. Dit proefschrift bevat dan ook, naast juridische, heel wat rechtssociologische, politicologische en criminologische elementen.

In een eerste deel wordt een analyse gemaakt van het concept "herstelrecht" en de mogelijke aanknopingspunten met tradities en dominante religies in de regio. In het op het traditionele retributieve strafrecht gebaseerde denken wordt het misdrijf of het conflict uit handen genomen van zowel dader als slachtoffer. In de herstelrechtelijke benadering wordt het juist belangrijk geacht om zowel dader als slachtoffer en bij uitbreiding 
ook de volledige gemeenschap te activeren bij het zoeken naar oplossingen voor het conflict, het ter verantwoording brengen van de dader en het herstellen van de emotionele en materiële schade. Het herstelrecht kan op verschillende wijzen geïmplementeerd worden. Uit het onderzoek blijkt dat de maximalistische benadering de meest realistische benadering is omdat het streeft naar de reïntegratie van alle betrokken partijen en dit streven tot primair doel stelt van de strafrechtsbedeling. Bij het hanteren van een conflictmanagementmodel moet ook rekening gehouden worden met sociaalculturele achtergronden. In verschillende landen van Afrika werden reeds herstelrechtelijke principes in de praktijk gebracht (cfr. de Zuid-Afrikaanse Waarheids- en Verzoeningscommissie). Tijdens het onderzoek werd duidelijk dat traditionele Afrikaanse wijzen van conflictafhandeling veel gemeen hebben met de herstelrechtelijke benadering. Dit betekent dat de gemeenschap betrokken wordt bij het conflict en dat het volledige proces in het teken staat van herstel en verzoening en niet zozeer van bestraffing. Bovendien blijkt uit dit onderzoek dat het herstelrechtelijk denken reeds binnen de Nigeriaanse geloofsgemeenschappen ingeburgerd is. Zowel de islam in het noorden van het land als het katholicisme in het zuiden bevatten herstelrechtelijke principes. Deze twee gegevens duiden op de aanwezigheid van een sociaalculturele draagkracht voor een herstelrechtelijke benadering.

In een volgend deel worden de achtergronden en oorzaken geduid van de conflicten in de Niger Delta en wordt onderzocht welke impact deze oorzaken hebben op de formele reactie op deze conflicten. De vele gewelddadige conflicten in de Niger Delta zijn niet te wijten aan etnisch radicalisme, maar aan hoge armoede en politieke verwaarlozing. Bovendien wordt de leefomgeving van de lokale bevolking ernstig aangetast door milieuvervuiling ten gevolge van de olie-exploitatie. Het wordt snel duidelijk wie de lusten en wie de lasten draagt. De federale regering en oliebedrijven genereren enorme winsten ten koste van de lokale bevolking, die haar grond verliest, waardoor huisvesting en voedselvoorziening in het gedrang komen (er zijn b.v. nog amper vissen te vinden in de door de oliebedrijven vervuilde meren), die zonder werk zit en volledig door de regering (en de plaatselijke oliebedrijven) aan haar lot wordt overgelaten,... De frustratie en onvrede van de bevolking is dan ook begrijpelijk. Op de steun van de regering hoeft de bevolking klaarblijkelijk niet te reken. Om de winsten veilig te stellen werd door de regering een aantal (onrechtvaardige) wetten aangenomen zoals de Petroleum Decree en de Land Use Decree, die de lokale gemeenschappen hun eigendomsrecht over de natuurlijke grondstoffen in hun regio ontzeggen.

Tot nog toe heeft de Nigeriaanse regering alles in het werk gesteld zodat de oliebedrijven ongestoord hun activiteiten kunnen verderzetten. Wetten werden aangenomen waardoor het mogelijk werd om bijvoorbeeld grond op te eisen. De oliebedrijven moeten zich niet druk maken over de milieuvervuiling want wetgevende initiatieven daartoe komen er niet. De wetten die voordelig zijn voor deze oliebedrijven en de staat zijn de enige wetten die effectief afgedwongen worden door politie en leger. Als er protest komt tegen de praktijken van de oliebedrijven, dan schakelt de regering het leger in om dit protest de kop in te drukken. Deze repressieve bena- 
dering heeft er enkel toe bijgedragen dat de conflicten op de spits gedreven worden. Uit verschillende studies blijkt dat traditionele samenlevingen zowel herstelrechtelijke als repressieve elementen in hun conflictafhandelingsmechanismen hanteren. Gezien de aansluiting met Afrikaanse tradities en de aard van de conflicten in de Niger Delta kan besloten worden dat een herstelrechtelijke benadering ook toegepast kan worden op andere conflicten dan louter strafrechtelijke. In de consolidatie van duurzame vrede betekent het toepassen van herstelrechtelijke principes een meerwaarde voor het uiteindelijke verzoeningsproces (zie Zuid-Afrika, Rwanda). Toch moeten ook lessen getrokken worden uit het verleden en moet men bij het implementeren van een herstelrechtelijke benadering de lokale situatie goed indachtig zijn.

Het implementeren van herstelrecht betekent ook dat er moet geïnvesteerd worden in het justitiële apparaat. Het moet een toegankelijk, effectief, efficiënt en professioneel systeem zijn dat de nodige legitimiteit heeft in de ogen van de burgers. Niet alleen kan het huidige Nigeriaanse strafrechtsysteem de werklast niet aan, door haar retributieve aanpak genereert ze ook te veel negatieve effecten (secundaire victimisatie, overbevolking, het volledig uitstoten van de dader uit de samenleving waardoor die moeilijkheden ondervindt bij de reïntegratie,...). Dit proefschrift betoogt het invoeren van herstelrechtelijke principes in de wijze waarop conflicten voorkomen en afgehandeld worden. Dergelijke hervormingen kunnen bovendien in een bredere context aanleiding geven tot democratische hervormingen waarbij lokale verantwoording, het respecteren van de mensenrechten en lokale inspraak centraal staan. 